\title{
Students' Views for a Research-Intensive School Curriculum in Psychology: Research-Teaching Nexus
}

\author{
Maria Limniou1, Rosie Mansfield ${ }^{2}$, Christos Petichakis ${ }^{3}$ \\ ${ }^{1}$ School of Psychology, University of Liverpool, Liverpool, UK \\ ${ }^{2}$ Manchester Institute of Education, University of Manchester, Manchester, UK \\ ${ }^{3}$ Academy, University of Liverpool, Liverpool, UK \\ Email: Maria.Limniou@liverpool.ac.uk, rosie.mansfield@postgrad.manchester.ac.uk, c.petichakis@liverpool.ac.uk
}

How to cite this paper: Limniou, M., Mansfield, R., \& Petichakis, C. (2019). Students' Views for a Research-Intensive School Curriculum in Psychology: Research-Teaching Nexus. Creative Education, 10, 796-813.

https://doi.org/10.4236/ce.2019.104059

Received: March 26, 2019

Accepted: April 25, 2019

Published: April 28, 2019

Copyright $\odot 2019$ by author(s) and Scientific Research Publishing Inc. This work is licensed under the Creative Commons Attribution International License (CC BY 4.0).

http://creativecommons.org/licenses/by/4.0/

\begin{abstract}
The aim of this investigation was to gain an insight into how the curriculum of a Psychology School at a research-intensive university could be enhanced based on cross-sectional student views from all years of study. The School curriculum was framed under the research-teaching nexus and 272 undergraduate students completed online questionnaires regarding their research expectations and their learning experiences. The parallel questionnaires were distributed to the three distinct cohorts of students $\left(1^{\text {st }}, 2^{\text {nd }}\right.$ and $3^{\text {rd }}$ year of students) at the beginning of the first semester of the 2016-2017 academic year. Descriptive statistics were used to describe the cohorts and summarize the data collected. Chi-square tests were used to make comparisons and identify differences between student research expectations and experiences from the School curriculum. The main findings of this investigation concur with other studies in identifying significant differences between entry level students (Year 1) and those who have experienced learning in second and third years of study. However, the aim of these questionnaires was to study the School curriculum under the perspective of 1) The role of teaching staff in research, 2) Research skills obtained or expected to obtain by students and 3) Research connected with learning process and real-world applications. Potential reasons of the differences of learning experiences amongst students in different years of study and their implications are related to research activities and students' interactions through dialogue and collaboration with their teachers and amongst their peers in the context of community by studying real-example applications.
\end{abstract}

\section{Keywords}

Research-Teaching Curriculum, Student Expectations and Experiences, 
Research Skills Development, Teacher-Student Relationships, Student Research Engagement

\section{Introduction}

Many researchers have studied how students engage in research activities and how the relationship between teaching and research might be realized (Brew, 2006; Healey \& Jenkins, 2009; Malcolm, 2014). Although the influence of research on teaching, in a traditional UK research-intensive university, can be found at the heart of its interdisciplinary curriculum portfolio, there still appears to be a no clear definition of undergraduate research inquiry in the way it can be interpreted (Healey, Jordan, Pell, \& Short, 2010; Malcolm, 2014), implemented (Mayson \& Schapper, 2012) and evaluated (Wagner, Garner, \& Kawulich, 2011) amongst programme teams and central educational support units. A number of attempts have been made, for example Griffiths (2004) and Healey (2005) provided a set of four labels and a visual typology to describe the research-teaching nexus and placed particular attention to the way the curriculum is structured and the emphasis placed on its delivery. Both researchers developed an educational vocabulary that has informed related discussions amongst practitioners over the years. However, one might argue that the range of terms used to capture the nexus of teaching and research appears to have perplexed discipline based academic staff with educational jargon (Valter \& Akerlind, 2010) and terms that are used interchangeably (Healey et al., 2010; Lightfoot \& Piotukh, 2015). One starts to wonder hence, if this area is of concern to education researchers, what students may be thinking as they go through their programmes of study?

Furthermore, many studies have focused on disciplinary perspectives, including how the nexus is realized in specific contexts and how students are experiencing relevant teaching practice in a research-intensive environment (Wagner, Garner, \& Kawulich, 2011; Wilson, Howitt, Wilson, \& Roberts, 2012). Robertson (2007), and Robertson and Blackler (2006) suggested that the relationship between research and teaching can be hierarchical depending on the disciplinary context and found that science related subjects (for example in physical sciences) are more likely to offer a weaker relation between research and teaching in undergraduate studies in comparison with humanities subjects. Barnett (2000) raised the issue of what "academic" means in each department; some disciplines have more of a hierarchy in research and knowledge. Thus, there are disciplines such as Psychology which can be seen to sit somewhere in between, with some more concrete, experimental subjects lending better themselves to student involvement in research.

Additionally, a White Paper which was presented to the UK Parliament in 2011 by the Department for Business Innovation and Skills (BIS) entitled "Higher Education: students at the heart of the system" stated that "Charters should emphasize that to pursue higher education is to belong to a learning 
community and the experience will be most enriching when it is based on a partnership between students and staff' (BIS, 2011: p. 33). More recently attention has turned to students' perceptions and opinions of the way they engage and learn within and as members of a research environment or scholarly community (Xia, Caulfield, \& Ferns, 2015). Findings from studies on students' perceptions presented benefits in relation to staff enthusiasm to talk about their research (Howitt, Wilson, Wilson, \& Roberts, 2010; Malcolm, 2014) and teaching staff being seen as credible experts and sharing knowledge with their students (Garde-Hansen \& Calvert, 2007; Lightfoot \& Piotukh, 2015). Furthermore, students appreciated the opportunity to be actively engaged in research as a way of co-producing knowledge, exposing themselves to research active environments and developing a range of skills (Cuthbert, Arunachalam, \& Licina, 2012).

However, the literature exploring student perceptions of the relevance of academics' research to their learning has also identified students' concerns and challenges they have faced. Lack of availability of teaching staff to support and engage students in meaningful research driven activities (Wilson, Howitt, Roberts, Åkerlind, \& Wilson, 2013; Hajdarpasic, Brew, \& Popenici, 2015) and students being kept at arm's length in relation to research that takes place around them (Al-Maktoumi, Al-Ismaily, \& Kacimov, 2016; Brew, 2006), highlight challenges that exist in both the way programmes are being designed and how students are encouraged or supported to engage with and have a positive overall learning experience in a research driven setting. As a result, universities are increasingly becoming keen on the notion of developing or enhancing learning through a "students as researchers" pedagogy (Healey, Flint, \& Harrington, 2014). The notion can occur through the overlapping areas of "learning teaching and assessment"; "pedagogy advice and consultancy"; the "scholarship of teaching and learning" and "subject based research and inquiry". The aim of the notion of supporting learning through a "students as researchers" method is to further enhance students' experience of research by increasing the number of opportunities available to develop students' complex problem solving and other transferable skills which are attractive to employers (Walkington, 2015). However, simply teaching transferable skills to students, such as learning about research methods, does not appear to be enough (Rust, 2002). According to Brewster, Pisani, Ramseyer \& Wise (2016) a university community-based on the notion of "students as researchers" which will "connect research to practice and policy and researchers and students to communities by specifying the area of research, university-community collaboration, and undergraduate education and development" (p. 54), could assist students to graduate and move on to postgraduate study or professional careers. Lately and based on the above aspects, Fung (2016) introduced the connected curriculum framework which consists of 6 dimensions of activity "enabling students to learn through active participation in research and inquiry" (p. 30). The key elements of this framework are the pedagogical perspectives that put emphasis on learning through active participation in research, student engagement with staff and on building inclusive com- 
munities. The framework promotes the connection of research with real-world applications/issues that facilitates learning process across the curriculum.

The aim of this investigation was to gain an insight into how the curriculum of a Psychology School in a research-intensive university could be enhanced by listening to the student voice, exploring the principles of the research-teaching nexus (Griffiths, 2004; Healey, 2005) and connected framework proposed by Fung (2016). Taking a cross-sectional view at each year of study the objectives of this investigation were to study if:

1) there is any difference between student expectations and experiences in the curriculum regarding research activities;

2) the role of teaching staff influences student attitudes towards research; and

3) the student research activities promote a connection with research communities and real-world applications.

\section{Methodology}

\subsection{Experimental Conditions}

This investigation took place in a School of Psychology, at a research-intensive University in the Northwest of England, during the first three weeks of the 2016-2017 academic year. Every undergraduate Psychology student undertakes compulsory modules related to the development of research skills. Broadly, the approach taken by the school over the three years of study maps to Healey and Jenkins' (2009) framework. Specifically, students are provided with the opportunity to gain experience of gathering information (research-led teaching), exploring other's ideas (research-tutored curriculum), evidencing and developing their own ideas (research-oriented curriculum) and framing their own enquiries by participating in real research (research-based curriculum). The pattern of students developing a research experience as part of the School's programme is based on the assumption that students gradually shift from an "audience" to "participants" role based on the way the curriculum has been structured for each year of study (Ozay, 2012). This is done through a planned transition from Research-led and Research-tutored activities (1st year of studies) to Research-tutored and Research-oriented (2nd year of studies) to Research-oriented and Research-based (3rd year of studies) (Figure 1).

Specifically, the first-year students are involved in completing small-scale research experiments and participating in small group discussions with their academic advisors in topics such as report writing and ethics. The second-year students are given study scenarios and asked to run through the analysis process for a given statistical test. Additionally, they are supervised by their academic advisor to run a small-scale collaborative research project. The second-year aims are to introduce students to qualitative methods of analysis and advanced quantitative analyses. The learning and teaching approaches discussed earlier aim to prepare students for their final third year research project in which they are expected to build upon the practical skills and knowledge acquired in their previous 


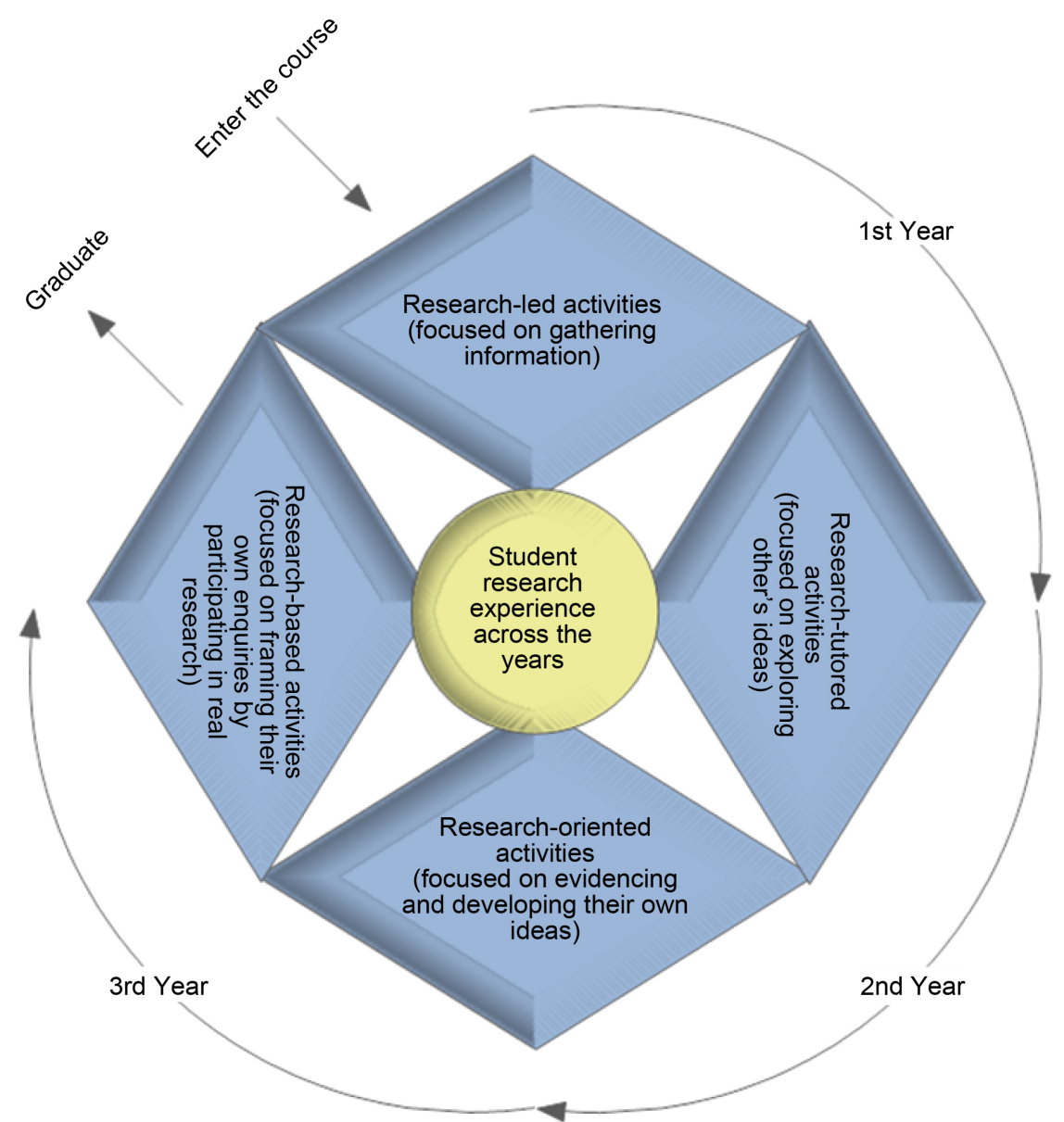

Figure 1. Student research experience throughout the whole programme.

years of study.

\subsection{Online Questionnaire and Participants}

The study was designed to be cross-sectional and data was collected simultaneously at all three years of the programme. Questionnaires were developed to support the data collection and they were administered online using Qualtrics software (www.qualtrics.com), which is a secure web-based survey system. Participants were also prevented from taking the online survey more than once by blocking the IP address using Qualtrics settings. The questionnaires were distributed through direct emails to student cohorts for each year of study. Table 1 illustrates the structure of the questionnaires. All sections were mirrored in the survey relating to student research expectations and experiences depending on the year of their studies (Year 1: expectations and Year 2 and 3: experiences). For example, the questionnaire item administered to first year students was presented as "In my year of study I expect to have learnt how to ..." while secondand third-year undergraduate students were asked "In my year of study I have learnt how to ...". The online questionnaires took approximately 10 minutes each to complete and student participation was anonymous. 
Table 1. Structure of the online questionnaire.

\begin{tabular}{|c|c|c|}
\hline \multirow{2}{*}{ Sections } & \multicolumn{2}{|c|}{ Title and short description } \\
\hline & Title & Description \\
\hline Section A & Personal Information & $\begin{array}{l}\text { Participant demographics and } \\
\text { personal characteristics. }\end{array}$ \\
\hline Section B & Role of teaching staff in research & $\begin{array}{l}\text { Examining how students recognize } \\
\text { the role of their teachers in relation } \\
\text { to research practice and its influence } \\
\text { to their learning. }\end{array}$ \\
\hline Section C & Research skills & $\begin{array}{l}\text { Exploring students' perceptions } \\
\text { on own development through } \\
\text { research skills in their learning. }\end{array}$ \\
\hline Section D & $\begin{array}{l}\text { Research as part of the learning } \\
\text { process and connection with } \\
\text { real-world applications }\end{array}$ & $\begin{array}{l}\text { Examining what students expect } \\
\text { from staff and learning activities } \\
\text { and connection with real-world } \\
\text { applications and key research } \\
\text { skills development. }\end{array}$ \\
\hline
\end{tabular}

This process captured the views of students who had already been part of the programme and those who had just started on the programme. The total number of respondents was 272 and the three cohorts invited to respond to this questionnaire based on their learning expectations and experiences in a research context are described in Table 2. Typical to most UK undergraduate psychology cohorts the average age of the sample was $19.65( \pm 3.12)$ and the majority of the students who participated were British (93\%) and female (88\%).

\section{Results}

By analyzing student responses from the second and the third-year students, there was no significant differences between the two groups. It was therefore assumed that the second and the third-year students had similar past research experiences of study in the programme. Thus, the study researchers decided to combine the second- and third-year student responses, which formed the experimental group (EG), to explore the students with previous research experiences on Psychology studies. The responses of the experimental group were compared to the first-year Psychology students, which formed the control group (CG), as the latter had no learning research experiences. Therefore, the first-year students were expressing their expectations of study in an undergraduate programme. A chi-square statistical analysis was conducted to compare CG and EG responses on the questions relating to students' connections with staff across the years of study. The results of this comparison as well as the mean (\%) of the group answers are presented in Table 3.

Overall, there is consistently significant differences between student expectations (CG) and student experiences (EG) within the undergraduate programme. For example, it seems that the second- and third-year group of students did not "know the research field of teaching staff in the School" (Q1) and they did not 
Table 2. Number of participants over the year of studies along with their research expections and experiences.

\begin{tabular}{|c|c|c|}
\hline & \multicolumn{2}{|c|}{ Title and short description } \\
\hline Year of Study & Student expectations and experiences & Number of student responses \\
\hline 1st Year & $\begin{array}{l}\text { Students starting in year } 1 . \\
\text { Their responses are aspirational as } \\
\text { they have no first-hand experience } \\
\text { of studying in Higher Education } \\
\text { or the way Psychology is } \\
\text { taught in university. }\end{array}$ & 167 (31\% of full cohort) \\
\hline 2nd Year & $\begin{array}{l}\text { Students starting in year } 2 . \\
\text { They were invited to reflect on } \\
\text { their experiences having already } \\
\text { completed year } 1 \text { of the programme }\end{array}$ & 56 (13\% of full cohort) \\
\hline 3rd Year & $\begin{array}{l}\text { Students starting in year } 3 \text {. } \\
\text { They were invited to reflect on } \\
\text { their experiences having already } \\
\text { completed years } 1 \& 2 \text { of the } \\
\text { programme. }\end{array}$ & 49 (13\% of full cohort) \\
\hline
\end{tabular}

have "stimulated discussions on a research topic" (Q2.4), although they already had at least a full year's experience in the programme. The EG students did not believe that they were encouraged in their year of study to "think and discuss concepts/cases/ideas with their teaching staff" (Q3.1) in order to "solve problems and discuss answers to relevant research questions" (Q3.2), whilst the CG students expected to have the above described experience. Results from all the above points show that the EG students did not feel encouraged by their teachers to "apply the knowledge to real-life situations" (Q3.3) and "provide real-life examples relevant to research topic" (Q3.5), whist the student expectations (CG) are high on the relevant questions.

Although there is a significant difference in all the statements regarding the way students appraised the involvement of teaching staff in research activities and their attitudes towards research and teaching, it seems that the EG group have developed research skills (Table 4) on searching in databases (Q4.1), formulating research hypotheses $(\mathrm{Q} 4.2)$, recruiting participants $(\mathrm{Q} 4.5)$, gathering and analyzing data (Q4.6 and Q4.7). However, there is a significant difference between student expectations and experiences in the development of their skills in research design (Q4.3), methodology understanding (Q4.4), interpret data (Q4.8), discuss the data analysis (Q4.9) and critical reflection on findings (Q4.11).

The CG and EG student responses on the final part of the questionnaire regarding the learning process and its connection with real-world applications are illustrated in Table 5. These include the students' involvement in tackling multi-layered challenges related to the links with appropriate internal and external communities and their involvement in acting as a research assistant. Based on student responses, there is no significant difference on those questions that 
Table 3. Students views on role of teaching staff involvement in research activities throughout the undergraduate curriculum.

\begin{tabular}{|c|c|c|c|}
\hline \multirow[b]{2}{*}{ Question } & \multicolumn{3}{|c|}{ Title and short description } \\
\hline & Statement & Mean (M) & $\begin{array}{l}\text { Chi-square results } \\
\quad(\alpha=0.001)\end{array}$ \\
\hline Q1 & $\begin{array}{l}\text { I know the research field of } \\
\text { teaching staff in my School. }\end{array}$ & $\begin{array}{l}\text { CG: } 87 \% \\
\text { EG: } 47 \%\end{array}$ & $\begin{array}{c}\chi^{2}(1,271)=54.33 \\
\mathrm{p}<0.001\end{array}$ \\
\hline Q2 & $\begin{array}{l}\text { I have found that teaching staff } \\
\text { in my School }\end{array}$ & & \\
\hline Q2.1 & made the research topic interesting to me & $\begin{array}{l}\text { CG: } 92 \% \\
\text { EG: } 63 \%\end{array}$ & $\begin{array}{c}\chi^{2}(1,271)=35.64 \\
\mathrm{p}<0.001\end{array}$ \\
\hline Q2.2 & $\begin{array}{l}\text { increased my understanding } \\
\text { of research topic }\end{array}$ & $\begin{array}{l}\text { CG: } 98 \% \\
\text { EG: } 77 \%\end{array}$ & $\begin{array}{c}\chi^{2}(1,271)=34.77 \\
\mathrm{p}<0.001\end{array}$ \\
\hline Q2.3 & were enthusiastic about his/her research & $\begin{array}{l}\text { CG: } 95 \% \\
\text { EG: } 73 \%\end{array}$ & $\begin{array}{c}\chi^{2}(1,271)=26.65 \\
\mathrm{p}<0.001\end{array}$ \\
\hline Q2.4 & stimulated discussions on a research topic & $\begin{array}{l}\text { CG: } 91 \% \\
\text { EG: } 51 \%\end{array}$ & $\begin{array}{c}\chi^{2}(1,269)=59.61 \\
\mathrm{p}<0.001\end{array}$ \\
\hline Q2.5 & $\begin{array}{l}\text { increased my awareness of } \\
\text { methodological issues }\end{array}$ & $\begin{array}{l}\text { CG: } 97 \% \\
\text { EG: } 73 \%\end{array}$ & $\begin{array}{c}\chi^{2}(1,271)=36.34 \\
\mathrm{p}<0.001\end{array}$ \\
\hline Q2.6 & $\begin{array}{l}\text { provided me with material which } \\
\text { increased my confidence (my } \\
\text { understanding) of research topic }\end{array}$ & $\begin{array}{l}\text { CG: } 92 \% \\
\text { EG: } 62 \%\end{array}$ & $\begin{array}{c}\chi^{2}(1,270)=41.37 \\
\mathrm{p}<0.001\end{array}$ \\
\hline Q2.7 & $\begin{array}{l}\text { stimulated my enthusiasm } \\
\text { for research topic }\end{array}$ & $\begin{array}{l}\text { CG: } 92 \% \\
\text { EG: } 56 \%\end{array}$ & $\begin{array}{c}\chi^{2}(1,271)=48.88 \\
\mathrm{p}<0.001\end{array}$ \\
\hline Q2.8 & $\begin{array}{l}\text { increased my awareness of issues faced by } \\
\text { research in the real-world }\end{array}$ & $\begin{array}{l}\text { CG: } 95 \% \\
\text { EG: } 70 \%\end{array}$ & $\begin{array}{c}\chi^{2}(1,271)=35.99 \\
\mathrm{p}<0.001\end{array}$ \\
\hline Q3. & I was encouraged in my year of study to & & \\
\hline Q3.1 & $\begin{array}{l}\text { think about concepts/cases/ideas and } \\
\text { discuss them with my teaching staff }\end{array}$ & $\begin{array}{l}\text { CG: } 93 \% \\
\text { EG: } 58 \%\end{array}$ & $\begin{array}{c}\chi^{2}(1,271)=49.49 \\
\mathrm{p}<0.001\end{array}$ \\
\hline Q3.2 & $\begin{array}{l}\text { solve problems and discuss answers to } \\
\text { relevant research questions }\end{array}$ & $\begin{array}{l}\text { CG: } 98 \% \\
\text { EG: } 66 \%\end{array}$ & $\begin{array}{c}\chi^{2}(1,271)=58.38 \\
\mathrm{p}<0.001\end{array}$ \\
\hline Q3.3 & $\begin{array}{l}\text { apply knowledge I acquired to real-life } \\
\text { situations with which I was familiar }\end{array}$ & $\begin{array}{l}\text { EG: } 92 \% \\
\text { CG: } 48 \%\end{array}$ & $\begin{array}{c}\chi^{2}(1,271)=68.20 \\
\mathrm{p}<0.001\end{array}$ \\
\hline Q3.4 & $\begin{array}{l}\text { synthesise and analyse } \\
\text { complex information }\end{array}$ & $\begin{array}{l}\text { EG: } 89 \% \\
\text { CG: } 67 \%\end{array}$ & $\begin{array}{c}\chi^{2}(1,270)=21.89 \\
\mathrm{p}<0.001\end{array}$ \\
\hline Q3.5 & $\begin{array}{l}\text { provide real-life examples } \\
\text { relevant to my research topic }\end{array}$ & $\begin{array}{l}\text { CG: } 89 \% \\
\text { EG: } 45 \%\end{array}$ & $\begin{array}{c}\chi^{2}(1,270)=66.89 \\
\mathrm{p}<0.001\end{array}$ \\
\hline
\end{tabular}

$\alpha$ is the limit of significance level, $M$ is the mean, $\chi^{2}(a, b)$ is the variance between groups, $\mathrm{p}$ is significance level, CG: 1st year students expressing their expectations, EG: 2nd and 3rd year students expressing their experiences.

related to reading research articles (Q5.3), the participation in a research project within the School (Q5.7), research techniques development (Q5.8) and the process of undertaking an independent research project as part of a module (Q5.9).

However, there is a significant difference between groups on activities which expected from students to be actively engaged with their teachers and/or other 
Table 4. Student views on research skills they developed.

\begin{tabular}{|c|c|c|c|}
\hline \multirow[b]{2}{*}{ Question } & \multicolumn{3}{|c|}{ Title and short description } \\
\hline & Statement & Mean $(\mathrm{M})$ & $\begin{array}{l}\text { Chi-square results } \\
\quad(\alpha=0.001)\end{array}$ \\
\hline Q4 & $\begin{array}{l}\text { In my year of study, I have } \\
\text { learned how to }\end{array}$ & & \\
\hline Q4.1 & $\begin{array}{l}\text { search in databases for research } \\
\text { outputs (e.g. journal papers, book } \\
\text { chapters, etc.) }\end{array}$ & $\begin{array}{l}\text { CG: } 98 \% \\
\text { EG: } 86 \%\end{array}$ & $\begin{array}{c}\chi^{2}(1,271)=11.39 \\
\mathrm{p}=0.001\end{array}$ \\
\hline Q4.2 & $\begin{array}{c}\text { formulate research hypotheses based } \\
\text { on a specific research topic }\end{array}$ & $\begin{array}{l}\text { CG: } 96 \% \\
\text { EG: } 88 \%\end{array}$ & $\begin{array}{l}\chi^{2}(1,270)=10.78 \\
\mathrm{p}=0.001\end{array}$ \\
\hline Q4.3 & design research & $\begin{array}{l}\text { CG: } 91 \% \\
\text { EG: } 70 \%\end{array}$ & $\begin{array}{c}\chi^{2}(1,270)=22.04, \\
\mathrm{p}<0.001\end{array}$ \\
\hline Q4.4 & understand research methodology & $\begin{array}{l}\text { CG: } 97 \% \\
\text { EG: } 85 \%\end{array}$ & $\begin{array}{c}\chi^{2}(1,269)=17.89, \\
\mathrm{p}<0.001\end{array}$ \\
\hline Q4.5 & recruit participants & $\begin{array}{l}\text { CG: } 79 \% \\
\text { EG: } 69 \%\end{array}$ & $\begin{array}{c}\chi^{2}(1,269)=4.96 \\
\mathrm{p}=0.026\end{array}$ \\
\hline Q4.6 & gather data & $\begin{array}{l}\text { CG: } 93 \% \\
\text { EG: } 90 \%\end{array}$ & $\begin{array}{c}\chi^{2}(1,271)=1.78 \\
\mathrm{p}=0.182\end{array}$ \\
\hline Q4.7 & analyse data & $\begin{array}{l}\text { CG: } 96 \% \\
\text { EG: } 89 \%\end{array}$ & $\begin{array}{c}\chi^{2}(1,270)=9.33 \\
\mathrm{p}=0.002\end{array}$ \\
\hline Q4.8 & interpret data & $\begin{array}{l}\text { CG: } 96 \% \\
\text { EG: } 81 \%\end{array}$ & $\begin{array}{c}\chi^{2}(1,269)= \\
21.731, \mathrm{p}<0.001\end{array}$ \\
\hline Q4.9 & discuss the data analysis & $\begin{array}{l}\text { CG: } 98 \% \\
\text { EG: } 77 \%\end{array}$ & $\begin{array}{c}\chi^{2}(1,271)=34.77 \\
\mathrm{p}<0.001\end{array}$ \\
\hline Q4.10 & $\begin{array}{l}\text { connect my findings with } \\
\text { others' research }\end{array}$ & $\begin{array}{l}\text { CG: } 89 \% \\
\text { EG: } 77 \%\end{array}$ & $\begin{array}{c}\chi^{2}(1,269)=9.71 \\
\mathrm{p}=0.002\end{array}$ \\
\hline Q4.11 & critically reflect on findings & $\begin{array}{l}\text { CG: } 95 \% \\
\text { EG: } 76 \%\end{array}$ & $\begin{array}{c}\chi^{2}(1,270)=23.52, \\
\mathrm{p}<0.001\end{array}$ \\
\hline Q4.12 & $\begin{array}{l}\text { share my research findings } \\
\text { with others }\end{array}$ & $\begin{array}{l}\text { CG: } 86 \% \\
\text { EG: } 45 \%\end{array}$ & $\begin{array}{c}\chi^{2}(1,270)=51.99 \\
\mathrm{p}<0.001\end{array}$ \\
\hline
\end{tabular}

$\alpha$ is the limit of significance level, $\mathrm{M}$ is the mean, $\chi^{2}(\mathrm{a}, \mathrm{b})$ is the variance between groups, $\mathrm{p}$ is significance level, CG: 1st year students expressing their expectations, EG: 2nd and 3rd year students expressing their experiences.

researchers through a research community within and/or outside the School. It seems that the EG group of students did not gain experience by hearing their teachers (Q5.1) or another researcher (Q5.2) discussing their research, and by examining a research paper produced by a member of staff within the School (Q5.4). Furthermore, the second and the third-year students stated that they did not gain experience on research by attending research seminars within the School (Q5.5) and/or research conferences (Q5.6). Additionally, it seems that the second and the third-year students had limited experience on the learning process of student involvement in a project acting as researchers (Q5.10) and the preparation of an output for a research conference or poster presentation (Q5.11). Finally, regarding student preferences on the development of a range of 
Table 5. Students views on making connections across subjects and out to the world.

\begin{tabular}{|c|c|c|c|}
\hline \multirow[b]{2}{*}{ Question } & \multicolumn{3}{|c|}{ Title and short description } \\
\hline & Statement & Mean $(\mathrm{M})$ & $\begin{array}{c}\text { Chi-square results } \\
\quad(\alpha=0.001)\end{array}$ \\
\hline Q5 & $\begin{array}{l}\text { Overall, I gained experience in } \\
\text { research processes by }\end{array}$ & & \\
\hline Q5.1 & $\begin{array}{l}\text { hearing a member of staff discussing } \\
\text { their research in a module }\end{array}$ & $\begin{array}{l}\text { CG: } 93 \% \\
\text { EG: } 73 \%\end{array}$ & $\begin{array}{c}\chi^{2}(1,271)=20.83 \\
\mathrm{p}<0.001\end{array}$ \\
\hline Q5.2 & $\begin{array}{l}\text { hearing a guest speaker discussing } \\
\text { their research in a module }\end{array}$ & $\begin{array}{l}\text { CG: } 88 \% \\
\text { EG: } 68 \%\end{array}$ & $\begin{array}{c}\chi^{2}(1,271)=15.36 \\
\mathrm{p}<0.001\end{array}$ \\
\hline Q5.3 & $\begin{array}{l}\text { reading a research paper at } \\
\text { my own time }\end{array}$ & $\begin{array}{l}\text { CG: } 78 \% \\
\text { EG: } 76 \%\end{array}$ & $\begin{array}{c}\chi^{2}(1,271)=0.166 \\
\mathrm{p}=0.684\end{array}$ \\
\hline Q5.4 & $\begin{array}{c}\text { examining a research paper } \\
\text { (statistical analysis/research } \\
\text { methodology/research design) } \\
\text { produced by a member of staff }\end{array}$ & $\begin{array}{l}\text { CG: } 83 \% \\
\text { EG: } 65 \%\end{array}$ & $\begin{array}{c}\chi^{2}(1,270)=12.64 \\
\mathrm{p}<0.001\end{array}$ \\
\hline Q5.5 & attending School's research seminars & $\begin{array}{l}\text { CG: } 87 \% \\
\text { EG: } 48 \%\end{array}$ & $\begin{array}{c}\chi^{2}(1,271)=46.45 \\
\mathrm{p}<0.001\end{array}$ \\
\hline Q5.6 & attending a research conference & $\begin{array}{l}\text { CG: } 75 \% \\
\text { EG: } 36 \%\end{array}$ & $\begin{array}{c}\chi^{2}(1,270)=40.65 \\
\mathrm{p}<0.001\end{array}$ \\
\hline Q5.7 & $\begin{array}{l}\text { being a participant in a research } \\
\text { project run in my School }\end{array}$ & $\begin{array}{l}\text { CG: } 96 \% \\
\text { EG: } 86 \%\end{array}$ & $\begin{array}{c}\chi^{2}(1,271)=10.25 \\
\mathrm{p}=0.003\end{array}$ \\
\hline Q5.8 & $\begin{array}{l}\text { developing research techniques (e.g. } \\
\text { interviewing, laboratory analysis, } \\
\text { design skills, statistical analysis, } \\
\text { archival skills, fieldwork skills) }\end{array}$ & $\begin{array}{l}\text { CG: } 97 \% \\
\text { EG: } 88 \%\end{array}$ & $\begin{array}{c}\chi^{2}(1,271)=7.75 \\
\mathrm{p}=0.005\end{array}$ \\
\hline Q5.9 & $\begin{array}{l}\text { undertaking an independent research } \\
\text { project as part of a module }\end{array}$ & $\begin{array}{l}\text { CG: } 84 \% \\
\text { EG: } 83 \%\end{array}$ & $\begin{array}{c}\chi^{2}(1,271)=0.013 \\
\mathrm{p}=0.908\end{array}$ \\
\hline Q5.10 & acting as a research assistant & $\begin{array}{l}\text { CG: } 83 \% \\
\text { EG: } 64 \%\end{array}$ & $\begin{array}{c}\chi^{2}(1,270)=12.25 \\
\mathrm{p}<0.001\end{array}$ \\
\hline Q5.11 & $\begin{array}{l}\text { preparing for a research conference } \\
\quad \text { or poster presentation }\end{array}$ & $\begin{array}{l}\text { CG: } 63 \% \\
\text { EG: } 40 \%\end{array}$ & $\begin{array}{c}\chi^{2}(2,271)=14.01 \\
\mathrm{p}<0.001\end{array}$ \\
\hline Q6 & I prefer teaching staff in my School to & & \\
\hline Q6.1 & $\begin{array}{l}\text { support me when the issue is } \\
\text { one of project management }\end{array}$ & $\begin{array}{l}\text { CG: } 90 \% \\
\text { EG: } 77 \%\end{array}$ & $\begin{array}{c}\chi^{2}(1,270)=9.15 \\
p=0.002\end{array}$ \\
\hline Q6.2 & $\begin{array}{l}\text { encourage me to become a } \\
\text { member of the scientific community }\end{array}$ & $\begin{array}{l}\text { CG: } 58 \% \\
\text { EG: } 64 \%\end{array}$ & $\begin{array}{c}\chi^{2}(1,271)=1.08 \\
\quad p=0.298\end{array}$ \\
\hline Q6.3 & $\begin{array}{l}\text { encourage me to critique and analyse } \\
\text { my own research work }\end{array}$ & $\begin{array}{l}\text { CG } 94 \% \\
\text { EG: } 88 \%\end{array}$ & $\begin{array}{c}\chi^{2}(1,271)=3.346 \\
\mathrm{p}=0.067\end{array}$ \\
\hline Q6.4 & $\begin{array}{l}\text { encourage me to reflect and } \\
\text { develop myself }\end{array}$ & $\begin{array}{l}\text { CG: } 97 \% \\
\text { EG: } 91 \%\end{array}$ & $\begin{array}{c}\chi^{2}(1,271)=4.057 \\
\mathrm{p}=0.044\end{array}$ \\
\hline
\end{tabular}

$\alpha$ is the limit of significance level, $M$ is the mean, $\chi^{2}(a, b)$ is the variance between groups, $\mathrm{p}$ is significance level, CG: 1st year students expressing their expectations, EG: 2nd and 3rd year students expressing their experiences.

professional attributes and connections between their academic and lifelong learning (Q6.1-Q6.4), such as project management, self-evaluation process, ref- 
lection and personal development, it seems that there are no significant differences based on students' responses.

Beyond the quantitative results, all study participants had the opportunity to leave text-based comments about their research experience within the School (e.g., what additional support they might need, suggestions for improving the way they conducted research, comments about staff involvement in their research learning process). In the responses submitted, there are useful examples of good practice in the way teaching staff supported students to connect their learning to real-world examples or to develop key research related skills. A third-year student commented as follows, "[gender of academic] encouraged discussions in their lectures and explained things in a compelling and enjoyable way, providing opportunities for us to link information to real life situations". Similarly, a second-year student mentioned the enthusiasm of a number of teaching staff in communicating their research, "[names of three academics] are fantastic and are always very enthusiastic and informative about their research". However, there were also examples of less effective practice commented on by students in different years of study, including comments such as "very much dependent on which staff are delivering information" (comment by year 3 student) or "I think there should be more support given in how to search databases and how to tell which are good journals to use" (comment by year 2 student). Additionally, another second-year student made the following point in relation to support they feel they need in analyzing research papers and their concerns of doing things right, "I feel as though we need to be told how to analyze research papers more and be presented more with the issues faced in the real world as I found that a lot of the time we had to find these things out ourselves and I didn't know if I was doing it right." A similar view, but this time from a first-year student who recognized the challenges they may face ahead and would like for appropriate support to be in place as part of their study was, "I would find it useful to be pointed in the right direction with the reading part of the course to avoid reading irrelevant texts".

\section{Discussion}

This investigation aims to look into how the curriculum of a School in a research-intensive university could be enhanced by exploring students' views (first-year students' expectations and second- and third-year students' experiences) under the principles of the research-teaching nexus (Griffiths, 2004; Healey, 2005). This investigation was conducted in a School of Psychology, as this discipline sits somewhere in between a practice-based science subject, and a conceptual discipline from humanities. For example, it is important for Psychology students to develop a wide range of employability skills such as numeracy, empirical research skills, ethical awareness, literacy, interdisciplinary team-work and communication skills, while they are studying brain and human behavior (Trapp et al., 2011). 
By comparing students' responses, it becomes apparent that significant differences exist between the two groups. In particular, the first-year students seem to have high expectations on the way the curriculum would give them opportunities to engage with research related to material and processes. According to Apedoe \& Reeves (2006), students having authentic experiences as part of a research culture become familiar and proficient with discipline specific processes of scientific inquiry. In doing so, existing evidence on the value of this learning experience points towards making learning meaningful, transferable to different contexts and building students' confidence towards life-long learning (John \& Creighton, 2011; Shaw, Holbrook, \& Bourke, 2013). However, the findings of this investigation showed a significantly reduced perception of students' experiences acquired against key research practices. Specifically, second- and third-year students appear to be less satisfied with their experiences, when comparing them with the expectations of their counterparts in the first year, against learning to "design research-Q4.3"; "understand research methodology-Q4.4"; "interpret data-Q4.8”. These are all core research related activities that students should be confident to employ as they progress in the curriculum in their programme of study. Additionally, second- and third-year students, expressed they had reduced learning research experiences in relation to opportunities they were given "discuss the data analysis-Q4.9"; "connect findings with others" "research-Q4.10"; "share my research findings with others-Q4.12". These last three concepts are fundamental to effective research practice and yet it appears to be the case that students, as they progress in the years of study in their curriculum, have reduced experiences to showcase and disseminate their work for wider benefit and to spread knowledge (Louw \& Moloi, 2013). Existing literature makes a case for developing appropriate avenues for students to disseminate the findings of the work they do during their study; these appear in the form of student research journals, conferences, blogs, posters or exhibitions (Jenkins \& Healey, 2011; Spronken-Smith et al., 2013; Walkington et al., 2011). Consequently, there seems to be a missed opportunity in relation to engaging students in such contexts which appears to be noticeable to the second- and third-year students based on their responses in the questionnaire. Brewster, Pisani, Ramseyer and Wise (2016) have explored how social issues and real-world interactions play critical roles in the way students gain skills, knowledge and develop their characters as part of a research community which is underpinned by effective collaboration with relevant partners. As such, there seems to be significant evidence to justify efforts being made to provide students with meaningful opportunities to experience and learn key research processes. However, different research processes were explored in this investigation which appeared to be less established as part of research-teaching nexus curriculum. The aforementioned points contrast the connected curriculum framework (Fung, 2016), which promotes a strengthened connection between research that is led by students and leads to real-world applications. Furthermore, the connected curriculum pro- 
motes a positive relationship between students and staff as part of a community of learners that are actively involved in shaping and informing the curriculum with latest developments in disciplinary research contexts.

The way teaching staff engage with students in relation to research activities appears to play a key role on how students perceive the value of this interaction to their learning experiences. Existing literature reports on students feeling empowered as a result of being trusted by their teachers to work on a research task, whilst at the same time students value having the independence and being challenged to pursue their own ideas and working closely with staff that are approachable and engaged with their learning needs (Cuthbert et al., 2012; Wilson, Howitt, Wilson, \& Roberts, 2012). At the same time, there is evidence that the teaching and research nexus has the potential to create significant concerns for students and teaching staff, for example as a result of increased class sizes or conflicting priorities which limit time available to have prolonged opportunities of engagement with students in research related practice (Brew \& Jewell, 2012; Geschwind \& Broström, 2015). In this investigation, students in the first year and those in second and third years appear to have similar views in relation to their preferences on the way teaching staff in their school should be engaged in the student learning process (Q6.1 to 6.4) (e.g., regarding the critique and analysis of student research work, and the reflection and development process encouraging students to be a member of a research community). This seems to be a significant point for further investigation in order for educational researchers to explore how a range of research activities could be designed and how the interactions between teachers and students should be formalized as to promote effective learning through discussions and reflections. Although the research-teaching nexus framework and the connected curriculum provided some generic guidelines which may be followed by a School, the actual research activities along with the interactions between of staff and students and among students should be investigated under the perspectives of what students are doing and how the dialogue between academic staff and students could stimulate student curiosity (Himanka, 2013).

A number of studies have expressed concerns on the way learning in a programme makes valued links with real-world applications (Brownell \& Kloser, 2015; Howitt et al., 2010; Zimbardi \& Myatt, 2014). In this study, a significant difference between the two groups of students was observed. Of interest to this investigation were various features of disseminating research that can be integrated into a programme of study to bring undergraduate students as close as possible to having a real-world or authentic research experience (Q5.1 to Q5.11). This focus on dissemination of research was driven by Fung's notion of the connected curriculum that places particularly emphasis on a student-led approach to connecting themselves with key stakeholders that are able to enhance their learning experience (Fung, 2017). This may be an effective way of exposing undergraduate students to research that happens around them, by their academics or research communities more broadly. To support the data analysis of ex- 
ploring links with real-world applications, a framework for promoting dissemination of undergraduate research and inquiry (UGRI) (Spronken-Smith et al., 2013) which maps dissemination activities to gradually acquired student autonomy in various settings, was used. By comparing students' responses, significant differences in the value first year students placed in attending research seminars, listening to external speakers, attending research conferences or working as a research assistant, were found. Second and third year students seem to be less satisfied with the experiences they gained through these processes. Perhaps, this points towards the challenges that students face when they are offered opportunities to put in practice what they have learnt and assume greater autonomy in and ownership of their actions as part of a research driven curriculum (Kamoun \& Fakhry, 2011; Stevenson \& O'Keefe, 2011). If the support that they have received has not adequately prepared them, or built sufficient confidence in them to engage productively with relevant assessment processes, as they progress through the years of the programme, they might be concerned with compromising their future employability prospects (Oliver, 2013).

Overall, based on the findings of this investigation, there is evidence of a measurable difference between student expectations early in the programme and student experiences across the different years of study. The reported differences between student expectations and experiences were observed across various conceptual and practical dimensions, such as how students recognize the role of their teachers, how they develop research skills throughout their studies, and what the connection is between learning processes, research communities and real-world applications. Although this investigation was designed to explore a psychology curriculum, key aspects of this study have been identified as significant for the curriculum of a research-intensive School across disciplines (Levy \& Petrulis, 2012; Matthews, Firn, Schmidt, \& Whelan, 2017; Ozay, 2012; Stappenbelt, 2013). However, the main implication of this study is on the way a conceptual research framework is integrated into a curriculum. Further consideration should be directed to connect staff research with their teaching in a way that meets the expectations of their students. Perhaps, a way to meet student expectations with experiences might be through integrating technology into the curricula. Thus, Schools may enhance student engagement with research activities and teacher-student relationships (Limniou \& Mansfield, 2019). Additionally, the complexity of Higher Education learning appears to point towards creating opportunities for engagement as part of a community that promotes dialogue as part of research based activities that students engage with. In doing this, students may be encouraged to assume a positive attitude towards research. Increasing student curiosity and enhancing their relationship with academic staff, students may connect their knowledge with scientific communities and real-world applications.

\section{Acknowledgements}

The authors received no financial support for the research and authorship of this 
article.

\section{Conflicts of Interest}

The authors declare no conflicts of interest regarding the publication of this paper.

\section{References}

Al-Maktoumi, A., Al-Ismaily, S., \& Kacimov, A. (2016). Research-Based Learning for Undergraduate Students in Soil and Water Sciences: A Case Study of Hydropedology in an Arid-Zone Environment. Journal of Geography in Higher Education, 40, 321-339. https://doi.org/10.1080/03098265.2016.1140130

Apedoe, X. S., \& Reeves, T. C. (2006). Inquiry-Based Learning and Digital Libraries in Undergraduate Science Education. Journal of Science Education and Technology, 15, 321-330. https://doi.org/10.1007/s10956-006-9020-8

Barnett, R. (2000). Supercomplexity and the Curriculum. Studies in Higher Education, 25, 255-265. https://doi.org/10.1080/713696156

Brew, A. (2006). Research and Teaching: Beyond the Divide. London: Palgrave Macmillan.

Brew, A., \& Jewell, E. (2012). Enhancing Quality Learning through Experiences of Research-Based Learning: Implications for Academic Development. International Journal for Academic Development, 17, 47-58. https://doi.org/10.1080/1360144X.2011.586461

Brewster, A. B., Pisani, P., Ramseyer, M., \& Wise, J. (2016). Building a University-Community Partnership to Promote High School Graduation and Beyond: An Innovative Undergraduate Team Approach. Journal of Applied Research in Higher Education, 8, 44-58. https://doi.org/10.1108/JARHE-10-2014-0093

Brownell, S. E., \& Kloser, M. J. (2015). Toward a Conceptual Framework for Measuring the Effectiveness of Course-Based Undergraduate Research Experiences in Undergraduate Biology. Studies in Higher Education, 40, 525-544.

https://doi.org/10.1080/03075079.2015.1004234

Cuthbert, D., Arunachalam, D., \& Licina, D. (2012). "It Feels More Important than Other Classes I Have Done”: An “Authentic” Undergraduate Research Experience in Sociology. Studies in Higher Education, 37, 129-142. https://doi.org/10.1080/03075079.2010.538473

Department for Business, Innovation and Skill (BIS) (2011). Higher Education: Students at the Heart of the System.

https://assets.publishing.service.gov.uk/government/uploads/system/uploads/attachme nt_data/file/31384/11-944-higher-education-students-at-heart-of-system.pdf

Fung, D. (2016). Engaging Students with Research through a Connected Curriculum: An Innovative Institutional Approach. Council on Undergraduate Research Quarterly, 37, 30-35. https://doi.org/10.18833/curq/37/2/4

Fung, D. (2017). Connected Curriculum for Higher Education. London: UCL Press. http://discovery.ucl.ac.uk/1558776/ https://doi.org/10.2307/j.ctt1qnw8nf

Garde-Hansen, J., \& Calvert, B. (2007). Developing a Research Culture in the Undergraduate Curriculum. Active Learning in Higher Education, 8, 105-116. https://doi.org/10.1177/1469787407077984

Geschwind, L., \& Broström, A. (2015). Managing the Teaching-Research Nexus: Ideals and Practice in Research-Oriented Universities. Higher Education Research \& Devel- 
opment, 34, 60-73. https://doi.org/10.1080/07294360.2014.934332

Griffiths, R. (2004). Knowledge Production and the Research-Teaching Nexus: The Case of the Built Environment Disciplines. Studies in Higher Education, 29, 709-726. https://doi.org/10.1080/0307507042000287212

Hajdarpasic, A., Brew, A., \& Popenici, S. (2015). The Contribution of Academics' Engagement in Research to Undergraduate Education. Studies in Higher Education, 40, 644-657. https://doi.org/10.1080/03075079.2013.842215

Healey, M. (2005). Linking Research and Teaching: Disciplinary Spaces. In R. Barnett (Ed.), Reshaping the University: New Relationships between Research, Scholarship and Teaching (pp. 30-42). Maidenhead, UK: Open University Press.

Healey, M. Flint, A., \& Harrington, K. (2014). Engagement through Partnership: Students as Partners in Learning and Teaching in Higher Education. York: Higher Education Academy.

https://www.heacademy.ac.uk/engagement-through-partnership-students-partners-lea rning-and-teaching-higher-education

Healey, M., \& Jenkins, A. (2009). Developing Undergraduate Research and Inquiry. York: Higher Education Academy.

https://www.heacademy.ac.uk/knowledge-hub/developing-undergraduate-research-an d-inquiry

Healey, M., Jordan, F., Pell, B. \& Short, C. (2010). The Research-Teaching Nexus: A Case Study of Students' Awareness, Experiences and Perceptions of Research. Innovations in Education and Teaching International, 47, 235-246. https://doi.org/10.1080/14703291003718968

Himanka, J. (2013). University Curriculum-Recent Philosophical Reflections and Practical Implementations. Creative Education, 4, 100-104.

https://doi.org/10.4236/ce.2013.412A2015

Howitt, S., Wilson, A., Wilson, K., \& Roberts, P. (2010). "Please Remember We Are Not All Brilliant": Undergraduates' Experiences of an Elite, Research-Intensive Degree at a Research-Intensive University. Higher Education Research \& Development, 29, 405-420. https://doi.org/10.1080/07294361003601883

Jenkins, A., \& Healey, M. (2011). Navigating between Teaching, Learning and Inquiry: Developing Students as Researchers. The International HETL Review, 1, 35-45.

John, J., \& Creighton, J. (2011). Researcher Development: The Impact of Undergraduate Research Opportunity Programmes on Students in the UK. Studies in Higher Education, 36, 781-797. https://doi.org/10.1080/03075071003777708

Kamoun, F., \& Fakhry, H. (2011). Improving the Nexus between Research and Teaching in Undergraduate IS Education. The Review of Business Information Systems, 15, 25-36. https://doi.org/10.19030/rbis.v15i2.4201

Levy, P., \& Pertulis, R. (2012). How Do First-Year University Students Experience Inquiry and Research, and What Are the Implications for the Practice of Inquiry-Based Learning? Studies in Higher Education, 37, 85-101.

https://doi.org/10.1080/03075079.2010.499166

Lightfoot, S., \& Piotukh, V. (2015). The Research-Teaching Nexus in Politics and International Relations in the UK: A Survey of Practices and Attitudes: Research-Teaching Nexus in Politics and IR. Politics, 35, 99-110. https://doi.org/10.1111/1467-9256.12045

Limniou, M., \& Mansfield, R. (2019). (Game-Based) Student Response Systems Engage Students with Research-Teaching Nexus Activities and Support Their Skills Development. Creative Education, 10, 36-47. https://doi.org/10.4236/ce.2019.101003 
Louw, A. H., \& Moloi, K. C. (2013). Teaching-Research-Innovation Nexus: Towards an Entrepreneurial University of Technology. Mediterranean Journal of Social Sciences, 4, 63-72. https://doi.org/10.5901/mjss.2013.v4n13p63

Malcolm, M. (2014). A Critical Evaluation of Recent Progress in Understanding the Role of the Research-Teaching Link in Higher Education. Higher Education, 67, 289-301. https://doi.org/10.1007/s10734-013-9650-8

Matthews, K. E., Firn, J., Schmidt, S., \& Whelan, K. (2017). A Comparative Study on Student Perceptions of Their Learning Outcomes in Undergraduate Science Degree Programmes with Differing Curriculum Models. International Journal of Science Education, 39, 742-760. https://doi.org/10.1080/09500693.2017.1304672

Mayson, S., \& Schapper, J. (2012). Constructing Teaching and Research Relations from the Top: An Analysis of Senior Manager Discourses on Research-Led Teaching. Higher Education, 64, 473-487. https://doi.org/10.1007/s10734-012-9505-8

Oliver, B. (2013). Graduate Attributes as a Focus for Institution-Wide Curriculum Renewal: Innovations and Challenges. Higher Education Research \& Development, 32, 450-463. https://doi.org/10.1080/07294360.2012.682052

Ozay, S. B. (2012). The Dimensions of Research in Undergraduate Learning. Teaching in Higher Education, 17, 453-464. https://doi.org/10.1080/13562517.2011.641009

Robertson, J. (2007). Beyond the "Research/Teaching Nexus": Exploring the Complexity of Academic Experience. Studies in Higher Education, 32, 541-556. https://doi.org/10.1080/03075070701476043

Robertson, J., \& Blackler, G. (2006). Students' Experiences of Learning in a Research Environment. Higher Education Research \& Development, 25, 215-229. https://doi.org/10.1080/07294360600792889

Rust, C. (2002). The Impact of Assessment on Student Learning: How Can the Research Literature Practically Help to Inform the Development of Departmental Assessment Strategies and Learner-Centred Assessment Practices? Active Learning in Higher Education, 3, 145-158. https://doi.org/10.1177/1469787402003002004

Shaw, K., Holbrook, A., \& Bourke, S. (2013). Student Experience of Final-Year Undergraduate Research Projects: An Exploration of "Research Preparedness". Studies in Higher Education, 38, 711-727. https://doi.org/10.1080/03075079.2011.592937

Spronken-Smith, R., Brodeur, J., Kajaks, T., Luck, M., Myatt, P., Verburgh, A. et al. (2013). Completing the Research Cycle: A Framework for Promoting Dissemination of Undergraduate Research and Inquiry. Teaching and Learning Inquiry: The ISSOTL Journal, 1, 105-118. https://doi.org/10.2979/teachlearninqu.1.2.105

Stappenbelt, B. (2013). The Effectiveness of the Teaching-Research Nexus in Facilitating Student Learning. Engineering Education, 8, 111-121.

https://doi.org/10.11120/ened.2013.00002

Stevenson, C., \& O’Keefe, J. (2011). Developing Students' Research and Inquiry Skills from Year One: A Research Informed Teaching Project from the University of Sunderland. Innovative Practice in Higher Education, 1, 1-26.

Trapp, A., Banister, P., Ellis, J., Latto, R. Miell, D., \& Upton, D. (2011). The Future of Undergraduate Psychology in the United Kingdom. York: Higher Education Academy. https://www.heacademy.ac.uk/system/files/future-undergrad-psych-uk.pdf

Valter, K., \& Akerlind, G. (2010). Introducing Students to Ways of Thinking and Acting like a Researcher: A Case Study of Research-Led Education in the Sciences. International Journal of Teaching and Learning in Higher Education, 22, 89-97.

Wagner, C., Garner, M., \& Kawulich, B. (2011). The State of the Art of Teaching Research 
Methods in the Social Sciences: Towards a Pedagogical Culture. Studies in Higher Education, 36, 75-88. https://doi.org/10.1080/03075070903452594

Walkington, H. (2015). Students as Researchers: Supporting Undergraduate Research in the Discipline in Higher Education. York: Higher Education Academy. https://www.heacademy.ac.uk/system/files/resources/Students\%20as\%20researchers_1. pdf

Walkington, H., Griffin, A. L., Keys-Mathews, L., Metoyer, S. K., Miller, W. E., Baker, R., \& France, D. (2011). Embedding Research-Based Learning Early in the Undergraduate Geography Curriculum. Journal of Geography in Higher Education, 35, 315-330. https://doi.org/10.1080/03098265.2011.563377

Wilson, A., Howitt, S., Roberts, P., Åkerlind, G., \& Wilson, K. (2013). Connecting Expectations and Experiences of Students in a Research-Immersive Degree. Studies in Higher Education, 38, 1562-1576. https://doi.org/10.1080/03075079.2011.633163

Wilson, A., Howitt, S., Wilson, K., \& Roberts, P. (2012). Academics' Perceptions of the Purpose of Undergraduate Research Experiences in a Research-Intensive Degree. Studies in Higher Education, 37, 513-526. https://doi.org/10.1080/03075079.2010.527933

Xia, J. (Cecilia), Caulfield, C., \& Ferns, S. (2015). Work-Integrated Learning: Linking Research and Teaching for a Win-Win Situation. Studies in Higher Education, 40, 1560-1572. https://doi.org/10.1080/03075079.2014.882302

Zimbardi, K., \& Myatt, P. (2014). Embedding Undergraduate Research Experiences within the Curriculum: A Cross-Disciplinary Study of the Key Characteristics Guiding Implementation. Studies in Higher Education, 39, 233-250.

https://doi.org/10.1080/03075079.2011.651448 